ARTICLE

https://doi.org/10.1057/s41599-019-0218-9

\title{
One giant leap for capitalistkind: private enterprise in outer space
}

Victor L. Shammas ${ }^{1} \&$ Tomas B. Holen ${ }^{2}$

\begin{abstract}
Outer space is becoming a space for capitalism. We are entering a new era of the commercialization of space, geared towards generating profits from satellite launches, space tourism, asteroid mining, and related ventures. This era, driven by private corporations such as Elon Musk's SpaceX and Jeff Bezos's Blue Origins, has been labeled by industry insiders as 'NewSpace'-in contrast to 'Old Space', a Cold War-era mode of space relations when (allegedly) slow-moving, sluggish states dominated outer space. NewSpace marks the arrival of capitalism in space. While challenging the libertarian rhetoric of its proponentsspace enterprises remain enmeshed in the state, relying on funding, physical infrastructure, technology transfers, regulatory frameworks, and symbolic support-NewSpace nevertheless heralds a novel form of human activity in space. Despite its humanistic, universalizing pretensions, however, NewSpace does not benefit humankind as such but rather a specific set of wealthy entrepreneurs, many of them originating in Silicon Valley, who strategically deploy humanist tropes to engender enthusiasm for their activities. We describe this complex as 'capitalistkind'. Moreover, the arrival of capitalism in space is fueled by the expansionary logic of capital accumulation. Outer space serves as a spatial fix, allowing capital to transcend its inherent terrestrial limitations. In this way, the ultimate spatial fix is perhaps (outer) space itself.
\end{abstract}

\footnotetext{
${ }^{1}$ Oslo Metropolitan University, Work Research Institute (AFI), Oslo, Norway. ${ }^{2}$ Independent scholar, Oslo, Norway. Correspondence and requests for materials should be addressed to V.L.S. (email: victor.shammas@gmail.com)
} 


\section{Introduction}

n 6 February 2018, the California-based Space Exploration Technologies Corp., also known as SpaceX, launched its first Falcon Heavy rocket, a powerful, partially reusable launch vehicle, into space from Cape Canaveral Launch Complex 39 in Florida. With its significant thrust and payload capacity, the Falcon Heavy had the ability to lift into orbit nearly 64 metric tons.... mass greater than a 737 jetliner loaded with passengers, crew, luggage and fuel' (SpaceX, 2018). Multiple reusable parts, including first-stage boosters (and, in later versions, composite payload fairing $)^{1}$ provided a lift capacity nearly twice that of the next-most powerful rocket in operation, the United Launch Alliance's (ULA) Delta IV Heavy, and at nearly one-third the cost. With this first Falcon Heavy test flight, which produced widespread public enthusiasm and outpourings of support from both politicians and industry observers, ${ }^{2}$ SpaceX demonstrated that private corporations were busy redefining the domain of space exploration. SpaceX seemed to usher in an era differing markedly from that other period of astronautical excitement, the Cold Warera space race between the United States and the Soviet Union. Additionally, visions once restricted to the domain of science fiction now seemed increasingly attainable, freed from the (alleged) impediments of slow-moving nation-states: with the ascendancy of private corporations like SpaceX, satellite launches, space tourism, asteroid mining, and even the colonization of Mars seemed increasingly achievable (Cohen, 2017; Dickens and Ormrod, 2007a, 2007b; Klinger, 2017; Lewis, 1996).

In this sense, SpaceX's Falcon Heavy also carried a crucial ideological payload: the very idea of private enterprise and capitalist relations overtaking outer space. ${ }^{3}$ The Falcon Heavy conveyed this idea quite concretely. Onboard the rocket was an electric car, a Tesla Roadster (said to be Elon Musk's personal vehicle), which functioned as the rocket's 'dummy load', playing David Bowie's 'Space Oddity' and 'Life on Mars?' on repeat on the car's stereo system. An enticing marketing stunt viewed by millions online through SpaceX's YouTube live stream-with 2.3 million concurrent views, it was the second biggest live stream in YouTube history (Singleton, 2018)-the Falcon Heavy test flight embraced the logic of 'cool capitalism' (Schleusener, 2014), with in-jokes referencing Douglas Adam's Hitchhiker's Guide to the Galaxy, while heralding the arrival of a commercialized space age, dubbed by industry insiders as the age of 'NewSpace'.

But how are we to understand NewSpace? In some ways, NewSpace signals the emergence of capitalism in space. The production of carrier rockets, placement of satellites into orbit around Earth, and the exploration, exploitation, or colonization of outer space (including planets, asteroids, and other celestial objects), will not be the work of humankind as such, a pure species-being (Gattungswesen), but of particular capitalist entrepreneurs who stand in for and represent humanity. Crucially, they will do so in ways modulated by the exigencies of capital accumulation. These enterprising capitalists are forging a new political-economic regime in space, a post-Fordism in space aimed at profit maximization and the apparent minimization of government interference. A new breed of charismatic, starry-eyed entrepreneurs, including Musk's SpaceX, Richard Branson's Virgin Galactic, and Amazon billionaire Jeff Bezos's Blue Origin, to name but a selection, aim at becoming 'capitalists in space' (Parker, 2009) or space capitalists. Neil Armstrong's famous statement will have to be reformulated: space will not be the site of 'one giant leap for mankind', but rather one giant leap for capitalistkind. ${ }^{5}$ With the ascendancy of NewSpace, humanity's future in space will not be 'ours', benefiting humanity tout court, but will rather be the result of particular capitalists, or capitalistkind, ${ }^{6}$ toiling to recuperate space and bring its vast domain into the fold of capital accumulation: NewSpace sees outer space as the domain of private enterprise, set to become the 'first-trillion dollar industry', according to some estimates, and likely to produce the world's first trillionaires (see, e.g., Honan, 2018) -as opposed to Old Space, a derisive moniker coined by enthusiastic proponents of capitalism-in-space, widely seen to have been the sole preserve of the state and a handful of giant aerospace corporations, including Boeing and Lockheed Martin, in Cold Warera Space Age.

Under Donald Trump's presidency, the adherents of NewSpace have found a ready political partner. The commercialization of outer space was already well under way with Obama's 2010 National Space Policy, which emphasized 'promoting and supporting a competitive U. S. commercial space sector', which was 'considered vital to...continued progress in space' (Tronchetti, 2013, p. 67-68). But the Trump administration has aggressively pursued the deregulation of outer space in the service of profit margins. Wilbur Ross, President Trump's Secretary of Commerce, has eagerly supported the private space industry by pushing the dismantling of regulatory frameworks. As Ross emphatically stated, 'The rate of regulatory change must accelerate until it can match the rate of technological change!' (Foust, 2018a). Trump has proposed privatizing the provision of supplies to the International Space Station (ISS) while re-establishing the Cold War-era National Space Council, which includes members from Lockheed Martin, Boeing, ULA, and a series of NewSpace actors, such as SpaceX and Blue Origin. Ross was visibly enthusiastic about SpaceX's Falcon Heavy launch in February 2018 and seemed to embrace Musk's marketing ploy. 'It was really quite an amazing thing', Ross said. 'At the end of it, you have that little red Tesla hurdling [sic] off to an orbit around the sun and the moon' (Bryan, 2018). That same month, Ross spoke before the National Space Council, commenting appreciatively that 'space is already a $\$ 330$ billion industry' that was set to become a 'multitrillion-dollar one in coming decades'. He noted that private corporations needed 'all the help we can give them' and said it was 'time to unshackle business activity in space' (Department of Commerce, 2018).

Secretary Ross's remarks followed on the heels of the American Space Commerce Free Enterprise Act, a U.S. House of Representatives bill introduced in 2017, which, in a remarkable volteface, unilaterally declared that 'space is not a global commons', a crucial departure from ratified international treaties that paved the way for private property rights and the exploitation of precious resources in outer space. In case anyone had missed this little-noticed policy démarche, tucked away in the midst of an obscure piece of legislation, one of Trump's supporters, the executive director of the National Space Council, Scott Pace, publicly reiterated that 'outer space is not...the "common heritage of mankind", not "res communis", nor is it a public good' (Pace, 2017). Instead, outer space was quickly being recast as a private good or a space for private property. As the United States became " "open for business" in space' (Smith, 2017), in the words of one Republican congressman, space itself was being opened up to the interests of private enterprise.

The Outer Space Treaty of 1967 established space as terra nullius. One of the treaty's premises is that no celestial body can be claimed as the property of any particular state, so that 'outer space...is not subject to national appropriation by claim of sovereignty, by means of use or occupation, or by any other means'. While this does not prevent nations from extracting resources from celestial bodies, there is a clear requirement that these activities benefit all of Earth's inhabitants (Tronchetti, 2013, p. 14; Lyall and Larsen, 2009), paving the way for kind of communism in space which precludes the proclivities of capitalistkind. As noted, however, the Outer Space Treaty's assertion of space as a commons has come under pressure in recent years, at 
first in the form of so many quasi-comical ventures, bordering on fraudulent shams, with a flourishing online trade in lunar property'- 'Everybody Is Saying It...Nothing Could Be Greater Than To Own Your Own Crater!' ${ }^{\prime}$-including the production of seemingly authentic land deeds that remain practically unenforceable and contravened by treaty obligations anyway. More recently, its status as commons has been denied by President Trump and leading US Republicans. Communism in space was a possibility only so long as space was materially inaccessible to capitalistkind: as space becomes a probable site of profitable ventures, the Outer Space Treaty's proto-communism must falter and fade away.

Certain parallels exist between the exploration and colonization of outer space and similar maritime ventures back on Earth. To take but one limited aspect of the overlapping legal issues raised by these two areas, that of resource exploitation: the 1982 United Nations Convention on the Law of the Sea (UNCLOS) established that the 'seabed and ocean floor' beyond a nation's territorial waters (or 'the Area') are the 'common heritage of mankind, the exploration and exploitation of which shall be carried out for the benefit of mankind as a whole'. Like outer space, Earth's seabed is part of the commons. Similarly, the International Seabed Authority, which was established to oversee the 1982 convention, is to 'provide for the equitable sharing of financial and other economic benefits derived from activities in the Area' (UN, 1982, p. 71). In principle, then, any profits arising from, e.g., the mining of polymetallic nodules, are to be shared with all of humankind, including 'developing States, particularly the least developed and the land-locked among them' (UN, 1982, p. 56). Whether this is likely is to happen is, according to a recent review, likely to be hampered by two factors. First, the commercial exploitation of seabed metals, which is first and foremost a technical issue, 'seems as far away as ever' (Wood, 2008). Second, and perhaps more importantly, the political climate surrounding the creation and ratification (with the exception of the United States) of the 1982 convention has now appreciably shifted: 'Much of the ideological passion that characterized the debates in the First Committee of the Third UN Conference on the Law of the Sea, and to some degree also in the Preparatory Commission, have now subsided' (Wood, 2008). As with outer space, the ocean floor becomes a legal site of contestation the moment states and corporations are technically capable of exploiting it.

This article adopts an approach broadly derived from the critical theory tradition to analyze NewSpace. Drawing on David Harvey's notion of spatial fixes, as well as key theoretical insights from such varied thinkers as Hegel, Marx, Bourdieu, and Deleuze and Guattari, this article asks in what ways the NewSpace paradigm can be rethought through a critical (neo-Marxist) political economy framework. Below, we advance three crucial arguments. First, there is an expedient conflation of capitalist interests with a universalizing notion of the interests of humanity. Second, the state continues to play an important role in supporting capital accumulation in space; a key tension in this area is the question of the continued role of the state in facilitating and financing NewSpace ventures-a role that is simultaneously downplayed and even, on occasion, dismissed by NewSpace actors themselves. Finally, we reassess the commercialization of space through Harvey's concept of the spatial fix, arguing that outer space serves as an important outlet for surplus capital, a site of knowledge production and technological innovation, and a potential reservoir of untapped raw materials. While the future is inherently uncertain, the article spotlights the expansive tendencies of global capital and describe the ways NewSpace actors themselves have come to view outer space as the probable future site of a postterrestrial form of capital accumulation.

\section{The universalization of capitalism}

The 2010s may very well be remembered as the 'Age of NewSpace', the decade when outer space was turned into a capitalist space, when private corporations pushed the price of launches, satellites, and space infrastructure downwards, exerting what industry insiders call the 'SpaceX effect' (Henry, 2018), centered on the technological achievement of 'reusability', recovering used rocket boosters for additional launches, promising to drastically reduce the price of going to space (Morring, 2016). As one report observes, 'Not only has the number of private companies engaged in space exploration grown remarkably in recent years, these companies are quickly besting their government-sponsored competitors' (Houser, 2017). What the rockets, shuttles, ships, and landing pods will carry beneath their payload fairing or in their cargo hold, however, along with supplies and satellites, is the capitalist worldview, a particular ideology-just as Robinson Crusoe, in Marx's ironic retelling in Capital, 'having saved a watch, ledger, ink and pen from the shipwreck... soon begins, like a good Englishman, to keep a set of books' (Marx, 1976, p. 170), brings with him English political economy-'Freedom, Equality, Property and Bentham', as Marx (1976, p. 280) says elsewhereto his desert island.

In early 2018, astronomers across the world learned that a New Zealand start-up, Rocket Lab, which aimed to launch thousands of miniature satellites into orbit around Earth (so-called 'smallsats'), had planned to launch a giant, shining 'disco ball'-the 'Humanity Star'-into orbit around Earth. It was an elaborate marketing stunt masked by humanistic idealism. 'No matter where you are in the world, or what is happening in your life', said Rocket Lab CEO Peter Beck, 'everyone will be able to see the Humanity Star in the night sky' (Amos, 2018). Many astronomers expressed outrage at these plans, fearing that the light from the Human Star would threaten their ability to carry out scientific observations. But while these astronomers were incensed by the idea of a bright geodesic object disrupting their ability to carry out observations, concerns with the effects of the arrival of capitalistkind on their ability to collect data were non-existent. The astronomical community was angered by the idea of a material, concrete, visible object polluting "pure" scientific data, but it paid less attention to the (invisible and abstract) recuperation of the night sky as it was brought into the fold of capitalism.

In an interview, Beck was quizzed about the Humanity Star and asked by a reporter about the difficulties of generating profits in space (Tucker, 2018). To this Beck replied, 'It has always been a government domain, but we're witnessing the democratization of it... [I]t [is] turning into a commercially dominated domain'. Beck established an equivalence established between the dissolution of space as the rightful domain of states and the advent of profitmaking ventures as signs of 'democratization'. In space, according to Beck's logic, democratization involves the disappearance of the state and the rise of capital. The argument, of course, is impeccably post-statist: on this account, states are monolithic, conservative Leviathans beyond the reach of popular control; corporations, on the other hand, are in principle representatives of the everyman: in the age of the start-up, any humble citizen could in theory become an agent of disruption, a force for change, an explorer of space, and a potential member of the cadre of capitalistkind. Following this logic, the question for the entrepreneurs of NewSpace is how to monetize outer space, which means turning space into a space for capital; their question is how they can deplanetarize capital and universalize it, literally speaking, that is, turn the Universe into a universe for capital. In this light, Peter Beck's distortion of democratic ideals appears eminently sensible, equating democratization with monetization, that is, capital liberated from its earthly tethers. 
Emblematic of this capitalist turn in space was the founding of Moon Express in 2011, composed of a 'team of prominent Silicon Valley entrepreneurs...shooting for the moon with a new private venture aimed at scouring the lunar surface for precious metals and rare metallic elements' (Hennigan, 2011). Following Google's Lunar XPRIZE - an intertwining of Silicon Valley and NewSpace's capitalistkind-which promised a $\$ 20$ million prize for the first private company to land a spacecraft on the Moon, travel 500 meters, and transmit high-definition images back to Earth, all by March 2018, ${ }^{9}$ Moon Express claimed that it would be capable of landing on the lunar surface and earn the cash prize. Their stated goal was twofold: first, to mine rare resource like Helium-3 (a steadily dwindling scarce resources on Earth), gold, platinum group metals, and water, and, second, to carry out scientific work that would 'help researchers develop human space colonies for future generations' (Ioannou, 2017). The ordering is telling: first profits, then humanity. These were the hollow, insubstantial promises of a venture-capitalized NewSpace enterprise: in early 2018, Google announced that none of the five teams competing for the Lunar XPRIZE, including Moon Express, would reach their stated objectives by the 31 March deadline and they were taking their money back (Grush, 2018). In this sense, it was typical for NewSpace in its formative years: a corporate field populated by (overly exuberant) private enterprises who promised more than they could deliver. But the belief in NewSpace is real enough. In a tome bursting with the optimism of NewSpace, Wohlforth and Hendrix claim that the commercial spaceflight industry is transforming our sense of possibility. Using Silicon Valley's money and innovative confidence, it will soon bring mass space products to the market' (2016, p. 7).

The trope of humanity plays a key role in the rhetoric of the adherents of NewSpace. To fulfill the objectives of NewSpace, including profit maximization and the exploitation of celestial bodies, the symbolic figure of a shared humanity serves a useful purpose, camouflaging the conquest of space by capitalism with a dream of humanity boldly venturing forth into the dark unknown, thereby also providing the legitimacy and enthusiasm needed to support bolster the legitimacy of NewSpace. So long as the stargazers and SpaceX watchers are permitted their fill of 'collective effervescence', to use Durkheim's (1995, p. 228) concept, capitalist entrepreneurs will be able to pursue their business interests more or less as they please. The spectacle of outer space is crucial in this regard.

Crucially, however, and despite this spectacle, SpaceX's technology might not necessarily be more sophisticated than its competitors or predecessors. Some industry insiders have rebuffed some of the more the spectacular claims of NewSpace's proponents, arguing that launch vehicle reusability requires a (perhaps prohibitively) expensive refurbishing of the rocket engines involved in launches: 'The economics will depend on how many times a booster can be flown, and how much the individual expense will be to refurbish the booster...each time' (Chang, 2017). Reusability may be a technological dead-end because of the inherently stressful effects of a rocket launch on the launch vehicle's components, with extreme limitations on reusability beyond second-use as well as added risks of malfunctions that customers and insurers are likely to wish to avoid. Furthermore, the Falcon Heavy still has not matched the power and payload capacity of NASA's Saturn V, a product of 1960s militaryindustrial engineering and Fordist state spending programs. What SpaceX and other NewSpace corporations do with great ingenuity, however, is to manage the spectacle of outer space, producing outpourings of public fervor, aided by a widespread adherence to the 'Californian Ideology' (Barbrook and Cameron, 1996), or post-statist techno-utopianism, in many postindustrialized societies.
The very centrality of these maneuvers has initiated a new phase in the history of capitalist relations, that of 'charismatic accumulation'-certainly not in the sense of any 'objective' or inherent charismatic authority, but with a form of illusio, to speak with Bourdieu, vested in the members of capitalistkind by their uncanny ability to spin mythologizing self-narratives. This has always been part of the capitalist game, from Henry Ford and onwards, but the charismatic mission gains a special potency in the grandiose designs of NewSpace's entrepreneurs. Every SpaceX launch is a quasi-religious spectacle, observed by millions capable of producing a real sense of wonder in a condition of (legitimizing) collective effervescence.

Outer space necessarily reduces inter-human difference to a common denominator or a shared species-being. An important leitmotiv in many Hollywood science fiction movies, including Arrival (2016), is that a first encounter with an alien species of intelligent beings tends to flatten all human difference (including ethnoracial and national categories), thereby restoring humankind to its proper universality (see also Novoa, 2016). Ambassadors of Earth as a whole, not representatives of particular nations, step forth to meet alien emissaries. But even in the absence of such an encounter, the search for habitable domains (or rather, profitable locales) beyond Earth will necessarily forge a shared conception of the human condition, initiated with the Pale Blue Dot photograph in 1990. Typical of this sentiment are the words of the astronomer Carl Sagan, who famously observed of this photograph: 'On it everyone you love, everyone you know, everyone you ever heard of, every human being who ever was, lived out their lives'.

This naïvely humanistic vision has been one of the dominant tropes in the discourse on space since the 1950s, and it remains strong today, as with the claims of the United Nations Office for Outer Space Affairs (UNOOSA) that their task is to 'uphold the vision of a more equitable future for all humankind through shared achievements in space'. This representational tendency mobilizes humanism to generate enthusiasm about space-related activities. But such representations are increasingly being recuperated by capitalist enterprise, so that it is not humankind but its modulation by space capitalists that will launch into the dark unknown. It is not humankind but capitalistkind that ventures forth. In early 2018, NASA was set to request $\$ 150$ million in its 2019 budget to 'enable the development and maturation of commercial entities and capabilities which will ensure that commercial successors to the ISS... are operational when they are needed', only one of many signs that space is becoming a space for capitalism. According to one estimate, the value of just one single asteroid would be more than $\$ 20$ trillion in rare earth and platinum-group metals (Lewis, 1996), a precious prize indeed for profit-hungry corporations. ${ }^{10}$ Even the UNOOSA spoke vociferously in favor of the commercialization of space, appealing variously to the 'industry and private sector' and elevating the 'space economy' to a central pillar in its Space2030 Agenda (including the 'use of resources that create and provide value and benefits to the world population in the course of exploring, understanding and utilizing space'), even as the UN agency falls back on a humanistic, almost social-democratic vision of the equitable distribution of benefits (and profits) from space mining, exploration, and colonization (UNOOSA, 2018).

We find evidence of this strategic humanism in all manner of pronouncements from NewSpace entrepreneurs. To take but one example: Naveen Jain, the chairman and co-founder of MoonEx, a lunar commercialization firm, has claimed that 'from an entrepreneur's perspective, the moon has never truly been explored'. The moon, Jain has claimed, 'could hold resources that benefit Earth and all humanity' (Hennigan, 2011). We should note the recourse to the trope of all of humanity by this 
NewSpace entrepreneur, mimicked in the 1979 Moon Agreement, a UN treaty, which also held that the Moon's resources are 'the common heritage of mankind' (Tronchetti, 2013, p. 13) ${ }^{11}$ In a purely factual sense, of course, Jain is wrong: Google Moon offers high-resolution images of the lunar surface, ${ }^{12}$ and the moon has already been explored, in the sense of being mapped, albeit rudimentarily and with room for further data collection. Crucially, however, these cartographic techniques have not been put to capitalist uses: mapping minerals, for instance, or producing detailed schemata that might one day turn the Moon into a 'gas station' for commercial space ventures, as Wilbur Ross, Trump's Secretary of Commerce, has proposed (Bryan, 2018). What is lacking, in short, are capitalist maps of the Moon, i.e., a cartography for capital. But as Klinger (2017: 199) notes, even though no one is 'actively mining the Moon' at present, at least 'six national space programs, fifty private firms, and one graduate engineering program, are intent on figuring out how to do so'; furthermore, Klinger draws attention to mapping efforts that have revealed high an abundance of rare earth metals, thorium, and iron in the Moon's 'Mare Procellarum KREEP' region (Klinger, 2017, p. 203).

We have already noted that it is not humanity, conceived as species-being, a Gattungswesen, that makes its way into space. The term Gattungswesen, of course, has a long intellectual pedigree, harking back to Hegel, Feuerbach, Marx, and others. The term can 'be naturally applied both to the individual human being and to the common nature or essence which resides in every individual man and woman', Allan Wood (2004, p. 17) writes, as well as 'to the entire human race, referring to humanity as a single collective entity or else to the essential property which characterizes this entity and makes it a single distinctive thing in its own right'. Significantly, the adherents of NewSpace often resort to the idea of humanity in its broad universality (e.g., Musk, 2017), but this denies and distorts the modulation of humanity by its imbrication with the project of global (and post-global, i.e., space-bound) capitalism. It is precisely the sort of false universality implied in the humanism of the supporters of NewSpace that Marx subjected to a scathing critique in the sixth of his Theses on Feuerbach. Here Marx noted that the human essence is not made up of some 'abstraction inherent in each single individual' (1998, p. 570). Instead, humans are defined by the 'ensemble of social relations' in which they are enmeshed. Under NewSpace, it is not humanity, plain and simple, that ventures forth, but a specific set of capitalist entrepreneurs, carrying a particular ideological payload, alongside their satellites, instruments, and supplies, a point noted by other sociologists of outer space, or 'astrosociologists' (Dickens and Ormrod, 2007a, 2007b).

\section{The spatial fix of outer space}

No longer terra nullius, space is now the new terra firma of capitalistkind: its naturalized terroir, its next necessary terrain. The logic of capitalism dictates that capital should seek to expand outwards into the vastness of space, a point recognized by a recent ethnography of NewSpace actors (Valentine, 2016, p. 1050). The operations of capitalistkind serve to resolve a series of (potential) crises of capitalism, revolving around the slow, steady decline of spatial fixes (see e.g., Harvey, 1985, p. 51-66) as they come crashing up against the quickly vanishing blank spaces remaining on earthly maps and declining (terrestrial) opportunities for profitable investment of surplus capital (Dickens and Ormrod, 2007a, p. 49-78).

A 'spatial fix' involves the geographic modulation of capital accumulation, consisting in the outward expansion of capital onto new geographic terrains, or into new spaces, with the aim of filling a gap in the home terrains of capital. Jessop (2006, p. 149) notes that spatial fixes may involve a number of strategies, including the creation of new markets within the capitalist world, engaging in trade with non-capitalist economies, and exporting surplus capital to undeveloped or underdeveloped regions. The first two address the problem of insufficient demand and the latter option creates a productive (or valorizing) outlet for excess capital. Capitalism must regularly discover, develop, and appropriate such new spaces because of its inherent tendency to generate surplus capital, i.e., capital bereft of profitable purpose. In Harvey's (2006, p. xviii) terms, a spatial fix revolves around 'geographical expansions and restructuring...as a temporary solution to crises understood...in terms of the overaccumulation of capital'. It is a temporary solution because these newly appropriated spaces will in turn become exhausted of profitable potential and are likely to produce their own stocks of surplus capital; while 'capital surpluses that otherwise stood to be devalued, could be absorbed through geographical expansions and spatio-temporal displacements' (Harvey, 2006, p. xviii), this outwards drive of capitalism is inherently limitless: there is no end point or final destination for capitalism. Instead, capitalism must continuously propel itself onwards in search of pristine sites of renewed capital accumulation. In this way, Harvey writes, society constantly 'creates fresh productive powers elsewhere to absorb its overaccumulated capital' (Harvey, 1981, p. 8).

Historically, spatial fixes have played an important role in conserving the capitalist system. As Jessop (2006, p. 149) points out, 'The export of surplus money capital, surplus commodities, and/or surplus labour-power outside the space(s) where they originate enabled capital to avoid, at least for a period, the threat of devaluation'. But these new spaces for capital are not necessarily limited to physical terrains, as with colonial expansion in the nineteenth century; as Greene and Joseph (2015) note, various digital spaces, such as the Internet, can also be considered as spatial fixes: the Web absorbs overaccumulated capital, heightens consumption of virtual and physical goods, and makes inexpensive, flexible sources of labor available to employers. Greene and Joseph offer the example of online high-speed frequency trading as a digital spatial fix that furthers the 'annihilation of space by time' first noted by Marx in his Grundrisse (see Marx, 1973, p. 524).

Outer space serves at least two purposes in this regard. In the short-to medium-term, it allows for the export of surplus capital into emerging industries, such as satellite imaging and communication. These are significant sites of capital accumulation: global revenues in the worldwide satellite market in 2016 amounted to $\$ 260$ billion (SIA, 2017, p. 4). Clearly, much of this activity is taking place 'on the ground'; it is occurring in the 'terrestrial economy'. But all that capital would have to find some other meaningful or productive outlet were it not for the expansion of capital into space. Second, outer space serves as an arena of technological innovation, which feeds back into the terrestrial economy, helping to avert crisis by pushing capital out of technological stagnation and innovation shortfalls.

In short, outer space serves as a spatial fix. It swallows up surplus capital, promising to deliver valuable resources, technological innovations, and communication services to capitalists back on Earth. This places outer space on the same level as traditional colonization, analyzed in Hegel's Philosophy of Right, which Hegel thought of as a product of the inner dialectic of civil society', which drives the market to 'push beyond its own limits and seek markets, and so its necessary means of subsistence, in other lands which are either deficient in the goods it has overproduced, or else generally backward in creative industry, etc.' (Hegel, 2008, p. 222). In this regard, SpaceX and related ventures are not so very different from maritime colonialists and the trader-exploiters of the British East India Company. But there is something new at stake. As the Silicon Valley entrepreneur Peter 
Diamandis has gleefully noted: 'There are twenty-trillion-dollar checks up there, waiting to be cashed!' (Seaney and Glendenning, 2016). Capitalistkind consists in the naturalization of capitalist consciousness and practice, the (false) universalization of a particular mode of political economy as inherent to the human condition, followed by the projection of this naturalized universality into space-capitalist humanity as a Fukuyamite 'end of history', the end-point of (earthly) historical unfolding, but the starting point of humanity's first serious advances in space.

What role, then, for the state? The frontiersmen of NewSpace tend to think of themselves as libertarians, pioneers beyond the domain of state bureaucracy (see Nelson and Block, 2018). 'The government should leave the design work and ownership of the product to the private sector', the author of a 2017 report, Capitalism in Space, advocates. 'The private companies know best how to build their own products to maximize performance while lowering cost' (Zimmerman, 2017, p. 27). One ethnographer notes that 'politically, right-libertarianism prevails' amongst NewSpace entrepreneurs (Valentine, 2016, p. 1047-1048). Just as Donald Rumsfeld dismissed the opponents to the Iraq War as 'Old Europe', so too are state entities' interests in space exploration shrugged off as symptoms of 'Old Space'. Elon Musk, we are told in a recent biography, unlike the sluggish Big State actors of yore, 'would apply some of the start-up techniques he'd learned in Silicon Valley to run SpaceX lean and fast...As a private company, SpaceX would also avoid the waste and cost overruns associated with government contractors' (Vance, 2015, p. 114). This libertarianism-in-space has found a willing chorus of academic supporters. The legal scholar Virgiliu Pop introduces the notion of the frontier paradigm (combining laissez-faire economics, market competition, and an individualist ethic) into the domain of space law, claiming that this paradigm has 'proven its worth on our planet' and will 'most likely...do so in the extraterrestrial realms' as well (Pop, 2009, p. vi). This frontier paradigm is not entirely new: a 'Columbus mythology', centering on the 'noble explorer', was continuously evoked in the United States during the Cold War space race (Dickens and Ormrod, 2016, pp. 79, 162-164).

But the entrepreneurial libertarianism of capitalistkind is undermined by the reliance of the entire NewSpace complex on extensive support from the state, 'a public-private financing model underpinning long-shot start-ups' that in the case of Musk's three main companies (SpaceX, SolarCity Corp., and Tesla) has been underpinned by $\$ 4.9$ billion dollars in government subsidies (Hirsch, 2015). In the nascent field of space tourism, Cohen (2017) argues that what began as an almost entirely private venture quickly ground to a halt in the face of insurmountable technical and financial obstacles, only solved by piggybacking on large state-run projects, such as selling trips to the International Space Station, against the objections of NASA scientists. The business model of NewSpace depends on the taxpayer's dollar while making pretensions to individual selfreliance. The vast majority of present-day clients of private aerospace corporations are government clients, usually military in origin. Furthermore, the bulk of rocket launches in the United States take place on government property, usually operated by the US Air Force or NASA. ${ }^{13}$

This inward tension between state dependency and capitalist autonomy is itself a product of neoliberalism's contradictory demand for a minimal, "slim" state, while simultaneously (and in fact) relying on a state reengineered and retooled for the purposes of capital accumulation (Wacquant, 2012). As Lazzarato writes, "To be able to be "laissez-faire", it is necessary to intervene a great deal' (2017, p. 7). Space libertarianism is libertarian in name only: behind every NewSpace venture looms a thick web of government spending programs, regulatory agencies, public infrastructure, and universities bolstered by research grants from the state. SpaceX would not exist were it not for state-sponsored contracts of satellite launches. Similarly, in 2018, the US Defense Advanced Research Projects Agency (DARPA) - the famed origin of the World Wide Web-announced that it would launch a 'responsive launch competition', meaning essentially the reuse of launch vehicles, representing an attempt by the state to 'harness growing commercial capabilities' and place them in the service of the state's interest in ensuring 'national security' (Foust, 2018b).

This libertarianism has been steadily growing in the nexus between Silicon Valley, Stanford University, Wall Street, and the Washington political establishment, which tend to place a high value on Randian 'objectivism' and participate in a long American intellectual heritage of individualistic 'bootstrapping' and (allegedly) gritty self-reliance. But as Nelson and Block (2018, p. 189-197) recognize, one of the central symbolic operations of capitalistkind resides in concealing its reliance on the state by mobilizing the charm of its entrepreneurial constituents and the spectacle of space. There is a case to be made for the idea that SpaceX and its ilk resemble semi-private corporations like the British East India Company. The latter, "incorporated by royal charter from Her Majesty Queen Elizabeth I in 1600 to trade in silk and spices, and other profitable Indian commodities," recruited soldiers and built a 'commercial business [that] quickly became a business of conquest' (Tharoor, 2017). SpaceX, too, is increasingly imbricated with an attempt on the part of a particular state, the United States, to colonize and appropriate resources derived from a particular area, that of outer space; it, too, depends on the infrastructure, contracts, and regulatory environment that thus far only a state seems able to provide. Its private character, like that of the East India Company, is troubled by being deeply embedded in the state. As one commentator has observed of SpaceX, 'If there's a consistent charge against Elon Musk and his high-flying companies...it's that they're not really examples of independent, innovative market capitalism. Rather, they're government contractors, dependent on taxpayer money to stay afloat' (cit. Nelson and Block, 2018, p. 189).

Perhaps this should not come as a surprise. As Bourdieu (2005, p. 12) observed, 'The economic field is, more than any other, inhabited by the state, which contributes at every moment to its existence and persistence, and also to the structure of the relations of force that characterize it'. The state lays out the preconditions for market exchanges. Under neoliberalism, the state is the preeminent facilitator of markets. The neoliberal state is not so much a Minimalstaat, night watchman state, or slim state as it is the prima causa of market society (see, e.g., Wacquant, 2012). Similarly, in the political theory of Deleuze and Guattari, any economic development presupposes the political differentiation caused by the state (Deleuze and Guattari, 2004a, p. 237-238). Even in the global environment of contemporary capitalism, the market cannot operate without the state becoming integrated with capitalism itself, as 'it is the modern state that gives capitalism its models of realization' (Deleuze and Guattari, 2004b, p. 480). For capitalism to survive in outer space, the state must create a regulatory environment, subsidize infrastructure, and hand down contracts - in short, assemble outer space as a domain made accessible in legal, technical, and economic ways.

\section{Universalizing capital}

As Earth's empty spaces are filled, as our planet comes to be shorn of blank places, capitalistkind emerges to rescue capitalism from its terrestrial limitations, launching space rockets, placing satellites into orbit, appropriating extraterrestrial resources, and, perhaps one day, building colonies on distant planets like Mars. But why limit ourselves to Mars? As of mid-2017, NASA's Kepler 
observatory had discovered more than 5000 exoplanets-planets that seem like promising alternatives to Earth, located at an appropriate distance from their respective suns in the famed 'Goldilocks zone'. These 'planetary candidates', as they are known - that is, candidates for the replacement of Earth, capable of supporting human life with only minimal technological augmentation or cybernetic re-engineering-are above all viable candidates for selection by specific capitalists seeking to discover new profitable ventures beyond the limits of an Earth-bound capitalism. Space reveals the impotence of the neoliberal, postFordist state, its incapacity and unwillingness to embark on gigantic infrastructural projects, to project itself outwards, and to fire the imagination of (actual) humankind. Capitalistkind steps in to fill the vacuum left behind by a state that lacks what Mann (2012, p. 170) calls 'infrastructural power'. The old question, the question of Old Space, was quite simply: is this planet a viable site for humankind, a suitable homeland for the reproduction of human life away from Earth? But the new question, the question for NewSpace, will be: can this celestial body support capitalistkind? Will it support the interests of capitalist entrepreneurs, answering to the capitalist desire for continued accumulation?

While some elements of the astrosociological community, such as the Astrosociology Research Institute (ARI), ${ }^{14}$ insist on elucidating the "human dimension" in outer space, Dickens and Ormrod recognize that this humanization-through-capitalism really involves the 'commodification of the universe' (2007b, p. 2). While Dickens and Ormrod develop similar arguments to those sketched here-from their concept of an 'outer spatial fix' to their argument about outer space becoming woven into circuits of capital accumulation-they were writing at a time when their remarks necessarily remained speculative: the commercialization of space was still in its infancy. In an inversion of Hegel's owl of Minerva, reality has since largely confirmed their ideas and caught up with theory. Above all, when considering the various ventures ongoing in space today, it is not so much the universalizing human dimension as the specifically capitalist dimension that is striking. With the advent of NewSpace, outer space is becoming not the domain of a common humanity but of private capital.

The arguments laid out above mirror an ongoing turn in critical scholarship away from the notion of the Anthropocene towards a more rigorously political-economic concept of Capitalocene, premised on the 'claim that capitalism is the pivot of today's biospheric crisis' (Moore, 2016, p. xi). Just as the exponents of the concept of Capitalocene emphasize that it is capitalism, and not humanity as such, that is the driving force behind environmental transformation, so too does the notion of capitalistkind emphasize that it is not humankind tout court but rather a set of specific capitalist entrepreneurs who are acting as the central transformative agents of and in outer space, with the 'ever-increasing infiltration of capital' into what was formerly the domain of the state (Dickens and Ormrod, 2007a, p. 6). We can also think about these issues in terms of what PhilippopoulosMihalopoulos (2015) terms 'spatial justice'. This concept captures the fact that struggles over justice are often struggles to occupy space, as the term is more conventionally understood, as with urban battles over the 'right to the city' (Harvey, 2008), to provide just one example. But the same also holds true for outer space: there is an ongoing struggle over the right to take up space in outer space. So far, the capitalist side appears to be winning. As the proto-communism of the Cold War-era Outer Space Treaty is abandoned-in tandem with the increased technological feasibility of exploiting resources and accumulating profits in outer space-spatial justice in outer space increasingly comes to mean the 'justice' of capital, capitalistkind taking the place of humankind. It is comparatively easy to declare that outer space is a commons, as the Outer Space Treaty did in the late 1960s, when that domain is, for all practical purposes, inaccessible to capital; with the heightened accessibility of outer space, however, it is unsurprising that central political agents, such as President Trump's administration, should seek to dismantle this regulatory framework and ensure the smooth functioning of capital accumulation beyond the terrains of Earth.

What kind of capitalism is being projected into space? The complexity of state-market relations is sufficient to force us to hedge against a simplified reading of space commercialization: it is not a matter of states against markets, as if the two were mutually exclusive. Instead, as Bratton (2015) suggests, we are witnessing the emergence of a 'stack', a complex intertwining of commercial, geopolitical, and technological concerns, which challenges previous notions of state sovereignty. This can be seen as a hybridized state-market form, with technology playing a central role in reciprocal processes of political and economic transformation. On the one hand, outer space was in some sense always already the domain of marketization, albeit to a limited extent, even during the Cold War, from the first commercial satellite launch in the early 1960s to President Ronald Reagan's implementation of the Commercial Space Launch Act of 1984, which aimed to encourage private enterprise to take an interest in an emerging launch market. As Hermann Bondi, the head of the European Space Organization, wrote in the early 1970s, 'It is clear...that there must be three partners in space, universities and research institutions on the one hand, the government on the second and industry on the third' (Bondi, 1971, p. 9).

On the other hand, outer space still remains firmly within the domain of the state and is likely to do so for the foreseeable future, with the likely continued importance of military uses of satellite technology and the weaponization of Earth's orbitcrucially, the Outer Space Treaty only prohibits nuclear arms and other 'weapons of mass destruction' in space, not conventional weapons, such as ballistic missiles. One novel element in this phase of capitalism-in-space is the interrelationship between Silicon Valley, NewSpace, and the state (see, e.g., Vance, 2015). Silicon Valley's capitalist class, including Amazon's Jeff Bezos, play an outsize role in NewSpace. Behind and around these figures, however, remains the state-through its weighty fiscal, regulatory, military, and symbolic investments. ${ }^{15}$ To take but one example: In June 2018, SpaceX won a $\$ 130$ million contract with the U.S. Air Force to launch an 'Air Force Space Command' satellite onboard a Falcon Heavy rocket (Erwin, 2018).

Fredric Jameson's (2003, p. 76) oft-quoted observation that it is easier to imagine the end of humankind than the end of capitalism, is realized in the ideals and operations of capitalistkind. Elon Musk has observed that the goal of SpaceX is to establish humankind as a 'multiplanetary species with a self-sustaining civilization on another planet' whose purpose is to counteract the possibility of a 'worst-case scenario happening and extinguishing human consciousness' (Vance, 2015, p. 5). But couldn't we view this idealistic assertion on behalf of humanity in another way? It is not human consciousness, over and against what the writer Kim Stanley Robinson (2017, p. 2) calls 'mineral unconsciousness' (i.e., the mute, geological reality of the natural universe), so much as a specifically capitalist consciousness that is at stake. While the actions of capitalistkind may primarily be aimed at ensuring the future survival of the human species, an additional result is to ensure that the very idea of capitalism itself will outlive a (distantly) possible extinction event. Capitalism is a self-replicating system, pushing to expand ever outwards, using a territorializing strategy of survival. As David Harvey notes, 'a steady rate of growth is essential for the health of a capitalist economic system, since it is only through growth that profits can be assured and the accumulation of capital be sustained' (1990, p. 180). In this 
respect, outer space is ideal: it is boundless and infinite. As Earth comes to be blanketed by capital, it is only to be expected that capital should set its sights on the stars above. The actions of capitalistkind serve to bolster the capitalist mode of production and accumulation: it is not only life but capital itself that must outlive Earth-even into the darkness of space.

Received: 30 October 2018 Accepted: 10 January 2019

Published online: 29 January 2019

\section{Notes}

1 A payload or rocket fairing is the 'nose cone' of the rocket, or 'launch vehicle' that protects its cargo (or 'payload'), such as satellites or scientific instruments, from the aerodynamic forces in play during a rocket's flight into space.

2 Emblematic of this tendency was US President Donald Trump's tweet upon learning of the successful Falcon Heavy test flight: 'Congratulations @ElonMusk and @SpaceX on the successful \#FalconHeavy launch. This achievement, along with @NASA's commercial and international partners, continues to show American ingenuity at its best!' The privatization of space is continuously imbricated with the broader geopolitical (or universo-political) ambitions of the world's dominant superpower, including the launching of satellites, perhaps even weapon systems, for the purposes of 'national security', which serves to complicate the rhetoric of libertarianism expressed by the proponents of NewSpace. Even capitalism-in-space is fundamentally shaped by the actions of the state, if only because markets are, as Bourdieu (2005) reminds us, created and upheld by the state.

3 In this article, 'outer space' is understood as the area extending past the so-called Kármán line, set at $100 \mathrm{~km}$ above Earth's sea level, including 'the moon and other celestial bodies', which follows the definition of outer space laid out in Article 1 of the Outer Space Treaty. As the space law scholar Fabio Tronchetti (2013: viii) notes, ' $[\mathrm{M}]$ any argue that the lower border of outer space should be set at an altitude of $100 \mathrm{~km}$ above sea level (62.5 miles)'. We follow this practice in this article, taking 'outer space' to be the region above this imaginary boundary as well as the objects and entities contained within it.

4 For a play-by-play account of the space industry, produced by and for industry insiders, one might consult the informative (but emic and adulatory) news portal, SpaceNews.com

5 Ironically, despite the NewSpace entrepreneurs' talk of saving humanity from a dying planet by turning humankind into a multiplanetary species (e.g., Musk, 2017), the accelerating NewSpace race may actually accelerate catastrophic global climate change, owing to the deleterious (and largely unmeasured) effects of burning liquid rocket fuels in the atmosphere (see Toohey et al., 2009), which may feed the imperative to find alternatives to Earth. For the first time in the report's history, the United Nations 2018 Quadrennial Global Ozone Assessment was set to include estimates of the effects of rocket launches on Earth's atmosphere.

6 In this article, the meaning of the term 'capitalistkind' is twofold. On the one hand, it denotes universalizing, humanistic representations of capitalist activities, where capitalism is portrayed as a system of and for the entirety of humankind, said to benefit the entire human species, and comes to be equated with humanity. On the other hand, the term points to a particular array of capitalist agents responsible for the operations of private enterprise in space. More than a pun, then, the idea of capitalistkind captures the strategic appropriation of humanistic universality by a particular group of ideologically self-conscious, spacefaring capitalists.

7 See Article II of the Treaty on Principles Governing the Activities of States in the Exploration and Use of Outer Space, including the Moon and Other Celestial Bodies (also known as the Outer Space Treaty) (e.g., UNOOSA, 2017, p. 4).

8 Interestingly, the Lunar Registry recognizes the problems of staking out property ownership in inaccessible locations: 'Remember: the only recognized historic precedent in international law for property ownership is actual occupation of that property', the company notes in a response to FAQs (emphasis in original). Thus, a commercial offering that appears to be part joke, part scam, actually emphasizes a serious point: it is relatively easy to declare that celestial bodies are a part of the commons so long as the usage and ownership of that commons remains only a theoretical, non-actualized possibility. Again, it is worth recalling that everyone can be a communist in space so long as space remains technologically inaccessible to capitalism.

9 See the XPRIZE website for more information on the rules and contestants: http:// lunar.xprize.org/.

10 Such estimates often assume, rather naively, that the price of commodities would not be adversely affected by the sudden influx of tremendous quantities of such resources into the marketplace. Lewis also falls into the humanist trap of thinking that the potential fruits of outer space will necessarily serve 'as resources for humankind' (1996, p. 98), rather for capitalistkind.
11 Tellingly, none of the major 'space powers' are parties to the 1979 Moon Agreement, precisely because of its proto-communistic demand that the spoils of the lunar surface and subsoil be shared equitably amongst all nations (see, e.g., Tronchetti, 2013, 13-14).

12 Google Moon offers a fascinating composite of extant lunar imagery, drawing on data collections maintained by the US Geological Survey, NASA's Ames Research Center, and the US National Academy of the Sciences' Universities Space Research Association, among others, see, e.g., https://www.google.com/moon/.

13 Consulting SpaceX's log of launches reveals that the overwhelming majority of launches take place from places like Vandenberg Air Force Base in California or Cape Canaveral in Florida, overseen by USAF and NASA, i.e., the state.

14 This and similar formulations can be found on the Astrosociology Research Institute's wide-roaming website: http://www.astrosociology.org/.

15 The complex intertwining of cutting-edge technologies, profit-maximizing corporations, and regulatory political structures in outer space has perhaps most memorably rendered been by the science fiction writer Kim Stanley Robinson in his Mars Trilogy (see, e.g., Robinson, 2017)

\section{References}

Amos J (2018) 'Disco ball' put into space from NZ. BBC.com. http://www.bbc.com/ news/science-environment-42808180. Accessed 24 Jan 2018

Barbrook R, Cameron A (1996) The Californian ideology. Sci Cult 6(1):44-72

Bondi H (1971) Europe's space effort and gravitation. In: Bondi H, Oliphant M, James LB, Mueller GE, Hage G eds. Pioneering in outer space: a course of lectures on selected topics in modern physics and space flight. Heinemann, London, p 9-61

Bourdieu P (2005) The social structures of the economy. Polity Press, Cambridge Bratton B (2015) The stack: on software and sovereignty. MIT Press, Cambridge Bryan B (2018) Trump's commerce secretary wants to turn the moon into a 'gas station for outer space'. Business Insider. http://www.businessinsider.com/ wilbur-ross-moon-space-gas-station-2018-2?r=US\&IR=T. Accessed 22 Feb 2018

Chang K (2017) Recycled rockets could drop costs, speed space travel. The New York Times, 30 March. https://www.nytimes.com/2017/03/30/science/space$\mathrm{x}$-reuseable-rockets-launch.html

Cohen E (2017) The paradoxes of space tourism. Tour Recreat Res 42(1):22-31

Deleuze G, Guattari F (2004a) Anti-oedipus: capitalism and schizophrenia. Continuum, London

Deleuze G, Guattari F (2004b) A thousand plateaus: capitalism and schizophrenia Continuum, London

Department of Commerce (2018) Secretary Ross: a bright future for U.S. leadership of space commerce. Commerce.gov. https://www.commerce.gov/news/ secretary-speeches/2018/02/secretary-ross-bright-future-us-leadership-spacecommerce. Accessed 21 Feb 2018

Dickens P, Ormrod JS (2007a) Cosmic society: towards a sociology of the universe Routledge, London

Dickens P, Ormrod JS (2007b) Outer space and internal nature: towards a sociology of the universe. Sociology 41(1):609-626

Dickens P, Ormrod JS (2016) Introduction: the production of outer space. In: Ormrod JS, Dickens P (eds) The palgrave handbook of society, culture and outer space. Palgrave Macmillan, Basingstoke, p 1-43

Durkheim É (1995) The elementary forms of religious life.The Free Press, New York, NY

Erwin S (2018) SpaceX wins $\$ 130$ million military launch contract for Falcon Heavy. SpaceNews, 21 June. https://spacenews.com/spacex-wins-130-million military-launch-contract-for-falcon-heavy/

Foust J (2018a) Commerce Department pressing ahead with commercial space regulatory reform. SpaceNews, 5 March. http://spacenews.com/commercedepartment-pressing-ahead-with-commercial-space-regulatory-reform/

Foust J (2018b) DARPA planning responsive launch competition. SpaceNews, 12 February. competition/

Greene DM, Joseph D (2015) The digital spatial fix. tripleC 13(2):223-247

Grush A (2018) It's official: no one is going to win the Google Lunar X Prize competition. The Verge. https://www.theverge.com/2018/1/23/16924020/ google-lunar-x-prize-competition-moon-no-winner. Accessed 23 Jan 2018

Harvey D (1985) The urbanization of capital. Basil Blackwell, Oxford

Harvey D (1990) The condition of postmodernity: an enquiry into the origins of cultural change. Blackwell, Cambridge

Harvey D (2006) The limits to capital.Verso, London

Harvey D (1981) The spatial fix-Hegel, von Thunen, and Marx. Antipode 13 (3):1-12

Harvey D (2008) The right to the city. New Left Rev 53(September-October):23-40

Hegel GWF (2008) Outlines of the Philosophy of Right. Oxford University Press, Oxford

Hennigan WJ (2011) MoonEx aims to scour moon for rare materials. Los Angeles Times, 8 April. http://articles.latimes.com/2011/apr/08/business/la-fi-moonventure-20110408 
Henry C (2018) France, Germany studying reusability with a subscale flyback booster. SpaceNews, 8 January. http://spacenews.com/france-germanystudying-reusability-with-a-subscale-flyback-booster/

Hirsch J (2015) Elon Musk's growing empire is fueled by $\$ 4.9$ billion in government subsidies. Los Angeles Times, 30 May. http://www.latimes.com/business/ la-fi-hy-musk-subsidies-20150531-story.html

Honan D (2018) The first trillionaires will make their fortunes in space. Big Think. http://bigthink.com/think-tank/the-first-trillionaires-will-make-theirfortunes-in-space

Houser K (2017) Private companies, not governments, are shaping the future of space exploration. Futurism, 12 June. https://futurism.com/privatecompanies-not-governments-are-shaping-the-future-of-space-exploration/

Ioannou L (2017) Billionaire closer to mining the moon for trillions of dollars in riches. CNBC.com. https://www.cnbc.com/2017/01/31/billionaire-closer-tomining-moon-for-trillions-of-dollars-in-riches.html. Accessed 31 Jan 2017

Jameson F (2003) Future city. New Left Rev 21(May-June):65-79

Jessop B (2006) Spatial fixes, temporal fixes and spatio-temporal fixes. In: Castree N, Gregory D (eds.) David Harvey: a critical reader. Blackwell Publishing, Malden, p 142-166

Klinger JM (2017) Rare earth frontiers: from terrestrial subsoils to lunar landscapes. Cornell University Press, Ithaca

Lazzarato M (2017) Experimental politics: work, welfare, and creativity in the neoliberal age. The MIT Press, London

Lewis JS (1996) Mining the sky: untold riches from the asteroids, comets, and planets. Helix Books, New York, NY

Lyall F, Larsen PB (2009) Space law: a treatise. Ashgate, Farnham

Mann M (2012) The sources of social power: volume 1, a history of power from the beginning to $\mathrm{AD} 1760$. Cambridge University Press, Cambridge

Marx K (1973) Grundrisse: introduction to the critique of political economy. Vintage Books, New York, NY

Marx K (1976) Capital: volume I. Penguin, London

Marx K (1998) The German ideology: including theses on Feuerbach and introduction to the critique of political economy. Prometheus Books, New York, $\mathrm{NY}$

Moore JW (ed.) (2016) Anthropocene or capitalocene? Nature, history, and the crisis of capitalism. PM Press, Oakland

Morring F Jr (2016) Making the shift from expendable to reusable launchers. Aviation Week. http://aviationweek.com/space/making-shift-expendablereusable-launchers. Accessed 2 Nov 2016

Musk E (2017) Making humans a multi-planetary species. New Space 5(2):46-61

Nelson PN, Block WE (2018) Space capitalism: how humans will colonize planets, moons, and asteroids. Palgrave Macmillan, Cham

Novoa A (2016) Alien life matters: reflections on cosmopolitanism, otherness and astrobiology. Cosmop Civil Soc J 8(1):4392. https://doi.org/10.5130/ccs. v8i1.4392

Pace S (2017) Space development, law, and values. Keynote speech, IISL Galloway Space Law Symposium Cosmos Club, Washington, D.C.

Parker M (2009) Capitalists in space. Sociol Rev 57(1):83-97

Philippopoulos-Mihalopoulos A (2015) Spatial justice: body, law, atmosphere. Routledge, New York, NY

Pop V (2009) Who owns the moon? Extraterrestrial aspects of land and mineral resources ownership. Springer, Heidelberg

Robinson KS (2017) Red Mars. Del Rey, New York, NY

Schleusener S (2014) Neoliberal affects: The cultural logic of cool capitalism. In: Fluck W, Pease DE (eds.) REAL: yearbook of research in english and American literature: volume 30: towards a post-exceptionalist American studies. Narr Verlag, Tübingen, p 307-326

Seaney R and Glendenning J (2016) Navigations through a legal asteroid belt. Harvard Law Pol Rev. http://harvardlpr.com/2016/03/14/navigationsthrough-a-legal-asteroid-belt/

SIA (2017) State of the satellite industry report. https://www.sia.org/wp-content/ uploads/2017/07/SIA-SSIR-2017.pdf. Accessed 15 Jan 2019

Singleton M (2018) SpaceX's Falcon heavy launch was YouTube's second biggest live stream ever. The Verge. http://www.theverge.com/2018/2/6/16981730/ spacex-falcon-heavy-launch-youtube-live-stream-record. Accessed $6 \mathrm{Feb}$ 2018
Smith M (2017) New commercial space bill clears House Committee. SpacePolicyOnline.com. https://spacepolicyonline.com/news/new-commercialspace-bill-clears-house-committee/. Accessed 8 June 2017

SpaceX (2018) Falcon heavy. http://www.spacex.com/falcon-heavy. Accessed 15 Jan 2019

Tharoor S (2017) Inglorious Empire: what the British did to India. Penguin, London

Toohey D, Peinemann M, Ross P (2009) Limits on the space launch market related to stratospheric ozone depletion. Astropolitics 7(1):50-82

Tronchetti F (2013) Fundamentals of space law and policy. Springer, Heidelberg

Tucker I (2018) One man's mission to conquer space. The Guardian, 11 February. https://www.theguardian.com/science/2018/feb/11/one-mans-mission-toconquer-space-peter-beck-humanity-star

UN [United Nations] (1982) United Nations convention on the law of the sea http://www.un.org/depts/los/convention_agreements/texts/unclos/unclos_e. pdf. Accessed 10 Dec 1982

UNOOSA [United Nations Office for Outer Space Affairs] (2017) United Nations treaties and principles on outer space. http://www.unoosa.org/pdf/ publications/ST_SPACE_061Rev01E.pdf. Accessed 15 Jan 2019

UNOOSA [United Nations Office for Outer Space Affairs] (2018) UNOOSA partnerships with industry and the private sector. http://www.unoosa.org/ oosa/en/informationfor/industryandprivatesector/index.html. Accessed 15 Jan 2019

Valentine D (2016) Exit strategy: profit, cosmology, and the future of humans in space. Anthropol Q 85(4):1045-1067

Vance A (2015) Elon Musk: how the billionaire CEO of SpaceX and Tesla is shaping our future. Virgin Books, London

Wacquant L (2012) Three steps to a historical anthropology of actually existing neoliberalism. Social Anthropol 20(1):66-79

Wohlforth C, Hendrix AR (2016) Beyond earth: our path to a new home in the planets. Pantheon Books, New York, NY

Wood AW (2004) Karl Marx (2nd Edition). Routledge, London

Wood M (2008) International Seabed Authority (ISA). Wolfrum R (ed.) In: Max Planck encyclopedia of public international law. Oxford University Press, Oxford. http://opil.ouplaw.com/view/10.1093/law:epil/9780199231690/law9780199231690-e1180?prd=EPIL. Accessed 15 Jan 2019

Zimmerman R (2017) Capitalism in space: private enterprise and competition reshape the global aerospace launch industry. Center for New American Security (CNAS), Washington, D.C.

\section{Additional information}

Competing interests: The authors declare no competing interests.

Reprints and permission information is available online at http://www.nature.com/ reprints

Publisher's note: Springer Nature remains neutral with regard to jurisdictional claims in published maps and institutional affiliations.

Open Access This article is licensed under a Creative Common Attribution 4.0 International License, which permits use, sharing, adaptation, distribution and reproduction in any medium or format, as long as you give appropriate credit to the original author(s) and the source, provide a link to the Creative Commons license, and indicate if changes were made. The images or other third party material in this article are included in the article's Creative Commons license, unless indicated otherwise in a credit line to the material. If material is not included in the article's Creative Commons license and your intended use is not permitted by statutory regulation or exceeds the permitted use, you will need to obtain permission directly from the copyright holder. To view a copy of this license, visit http://creativecommons.org/ licenses/by/4.0/

(C) The Author(s) 2019 